\title{
Association of the Val66met polymorphism and risk of obesity, systematic review and meta-analysis
}

\author{
Aqil M. Daher ${ }^{1 *}$, Halyna Lugova ${ }^{1}$, Methil Kannan Kutty², Igor Khalin ${ }^{1}$ \\ ${ }^{1}$ Faculty of Medicine and Defence Health, National Defence University of Malaysia, Kuala Lumpur, Malaysia. \\ ${ }^{2}$ Lincolin University College, Petaling Jaya, Selangor, Malaysia.
}

\begin{tabular}{l}
\hline ARTICLE INFO \\
\hline Received on: $20 / 08 / 2019$ \\
Accepted on: $21 / 10 / 2019$ \\
Available online: 03/01/2020
\end{tabular}

\section{Key words:}

Val66Met, obesity,

meta-analysis.

\begin{abstract}
Single nucleotide polymorphism of brain derived neurotropic factor gene, also known as Val66Met or rs6562, was found to be linked to obesity. However, reports on the link between this gene variant and obesity in Caucasian and Asian populations are inconsistent. A meta-analysis was, therefore, performed to determine the association between Val66Met polymorphism and the risk of obesity. Electronic databases, including Embase, CINAHL, and PubMed, were searched for relevant studies published before November 2018. Random effects model was used to calculate the pooled estimate based on the heterogeneity test results. Data were obtained from 11 studies involving 13,153 individuals with obesity and 18,689 non-obese individuals. The overall estimated odds ratio did not support the proposed association (OR $0.9,95 \%$ CI $0.793-1.136$ ). Stratified analysis, however, showed that Val/Val genotype is associated with increased risk of obesity among adults (OR 1.135, 95\% CI 1.001-1.286) but associated with a reduced risk among adolescents $(\mathrm{OR} 0.61,95 \% \mathrm{CI}=0.376,0.984)$. The results highlight the role of confounding factors that need to be addressed when making inference.
\end{abstract}

\section{INTRODUCTION}

The prevalence of obesity has reached alarming proportions with more than $39 \%$ of adults aged 18 years and above being overweight and 13\% as obese in 2014 (WHO, 2014a). Childhood obesity likewise also shows an increasing trend. In 2013, the number of overweight children under the age of 5 years was estimated to be over 42 million (WHO, 2014b). The cost of treating obesity and associated comorbidities, and prevention programs has become onerous to all nations in the world (Wang et al., 2011).

The crucial role of gene mutation/polymorphism in obesity is evident from a plethora of published reports. Genome wide-linkage studies provided evidence that around 253 trait loci implicated in obesity-linked phenotypes (Meyre et al., 2010).

\section{${ }^{*}$ Corresponding Author}

Aqil M. Daher, Faculty of Medicine and Defence Health, National Defence University of Malaysia, Kuala Lumpur, Malaysia.

E-mail:Draqiil38@gmail.com
Accumulating evidence suggests that common genetic variants or single-nucleotide polymorphisms (SNPs) may be a contributing factor to the obesity epidemic. Brain derived neurotropic factor (BDNF) is a type of neurotrophin encoded by the BDNF gene. This protein supports the growth and differentiation of neurons in the central nervous system. Although the function of BDNF is related to long-term memory, neuroplasticity, and growth of neurons (Khalin et al., 2015), a polymorphism of its gene was found to be related to obesity, where it was thought to suppress food intake through hippocampal signaling (El-Gharbawy et al., 2006; Monteleone et al., 2004). The rs6265, also known as Val66Met, is a single nucleotide Polymorphisim (SNP) of $B D N F$ gene found to be linked to obesity. The more common $\mathrm{G}$ allele encodes for Valine (Val), while the A allele encodes for Methionine (Met). Accordingly, three genotypes emerge, GG (or Val/Val), AA (or Met/Met and GA (or Val/Met).

$B D N F$ Val66met polymorphism has been associated with disorders, such as Schizophrenia (Eisenberg et al., 2013; Gratacòs et al., 2007; Suchanek et al., 2013), depression (Hosang et al., 2014), anxiety (Chen et al., 2006), eating disorders (Gratacòs et al., 2007), and some other disorders like sleeping disorder and tardive dyskinesia (Bachmann et al., 2012; Miura et al., 2014). 
However, considerable attention has been given to its potential association with obesity among the different populations (Beckers et al., 2008; Friedel et al., 2005; Hotta et al., 2009; Ja'afaruSani et al., 2012; León-Mimila et al., 2013; Marti et al., 2009; MoralesMarín et al., 2016; Perkovic et al., 2013; Skledar et al., 2012; Sustar et al., 2016; Thorleifsson et al., 2009; Timpano et al., 2011; Xi et al., 2011).

Generally, SNPs have modest impact on individual susceptibility to common forms of obesity, but due to their high frequency, they may have a large contribution to obesity in a given population (Lyon and Hirschhorn, 2005). The positive link betweenVal66Met and obesity was not ascertained in all published reports. Small sample size of the individual studies may have limited the power and generalizability of the findings. Thus, this meta-analysis was performed to ascertain the association between rs6562 and obesity.

\section{MATERIALS AND METHODS}

\section{Search strategy}

Two independent researchers conducted the search of the relevant articles in three major databases, Embase, CINHAL, and PubMed, using a different combination of the following keywords that paired "Val66Met," "rs6265," "G196A," "BDNF," and "SNP" with "obesity," and separately, with "BMI." A third researcher cross-checked and validated the articles selected from the databases. Any disagreement was discussed and resolved by the researchers. After the initial screening of the articles for inclusion criteria, a manual search of the lists of extracted articles was done to ensure better coverage of the topic. In addition, the literature search was supplemented by utilizing Google Scholar. Direct contacts were made with four authors to clarify the results. The literature search was updated in November 2018.

\section{Study eligibility and selection criteria}

We assessed the quality of each study based on the contents, methodology, and appropriateness for inclusion. Inclusion criteria were as follows: 1) observational studies; 2) studies examining the relationship between $B D N F$ Val66Met polymorphism (including genotype and allele frequencies) and the risk of obesity; 3) studies reporting the measure of association as odds ratio (OR); and 4) studies in English. Studies on eating disorders or animal or experimental studies, reviews, meta-analysis, editorials, abstract, and unpublished reports were excluded.

\section{Data extraction}

Data including the authors' name, year of publication, country (ethnicity), age (mean and SD), number of participants, genotype, and allele frequency distribution according to the obesity status, measure of association reported as OR and $95 \%$ confidence interval (CI) were extracted whenever available.

\section{Statistical analyses}

The OR with $95 \%$ CI from the selected studies was used to assess the association of obesity and Val66Metpolymorphism. Data from individual studies were extracted for calculation of OR as the effect size of interest. The Val/Val genotype was used as the test group, while Met allele (Met/Met + Val/Met) served as a reference group. Forest plot was used to depict the individual studies and pooled effect size. Random effects model was used to calculate the pooled estimate. Heterogeneity was assessed with Tau-squared, which reflects variance of true effect sizes, and $I^{2}$ statistic, which reflects the percentage of variation among true effect sizes not due to sampling error (Higgins and Thompson, 2002). A $p$ value of less than $<0.05$ was indicative of significant heterogeneity among the studies. Publication bias was assessed through funnel plot along with Begg's and Egger's regression statistics. Sensitivity analysis was performed using sequential omission of individual studies in every comparison. All data were entered and analyzed using comprehensive meta-analysis software v.2.

\section{RESULTS}

The initial search yielded 912 records. Screening by title resulted in 108 records related to the keywords. After examining abstracts from each of the records, we excluded 31 articles that were unrelated to val66met gene and 27 reports on disorders other than obesity. Another 20 reports were excluded as they were either reviews, meta-analyses, animal studies, and abstracts or being written in a language other than English.

The total number of full-text articles, which were eligible for data extraction, was 30 . Out of the 30 studies, 16 studies were excluded as they did not include reports on the association between Val66Met polymorphism (including genotype/allele frequency) and obesity. Further exclusion included studies in which the measure of association was either ambiguous (León-Mimila et al., 2013) or rejected by the software due to problematic confidence interval of the odds ratio (Timpano et al., 2011; Wu et al., 2010) or where the authors did not reply to our queries, leaving 11 eligible studies for the meta-analysis (Fig. 1).

\section{Characteristics of the participating studies}

The characteristics of individual studies are shown in Table 1. Most of the studies were conducted on adults except for four studies (Friedel et al., 2005; Ja'afaruSani et al., 2012; Skledar et al., 2012; Xi et al., 2011), which were conducted on adolescents. Participants in three of the studies were Asians (Hotta et al., 2009; Ja'afaruSani et al., 2012; Wang et al., 2011) and the rest were Caucasians and or Americans. Perkovic et al. (2013) reported data from three different time periods and were considered individually, while Beckers et al. (2008) reported data from a sample of female subjects. All studies had reported in frequency tables that allowed for computation of OR except (Thorleifsson et al., 2009) who only reported an adjusted OR. In total, 11 studies involving 13,153 individuals with obesity and 18,689 non-obese individuals were included in this analysis.

\section{Association of val66met and obesity}

The odds ratio of obesity for Val/Val versus Met carriers of the individual studies showed a wide variation. The overall pooled estimate (OR 0.9, 95\%CI 0.793, 1.136) showed no significant association between Val66Met genotype and obesity. However, when studies were stratified according to age group, Val/Val genotype appeared as a risk factor for obesity among adults (OR $1.135,95 \% \mathrm{CI}=1.001,1.286$ ), while it was protective among adolescents (OR 0.61, 95\% CI =0.376, 0.984) (Figs. 2-4). 


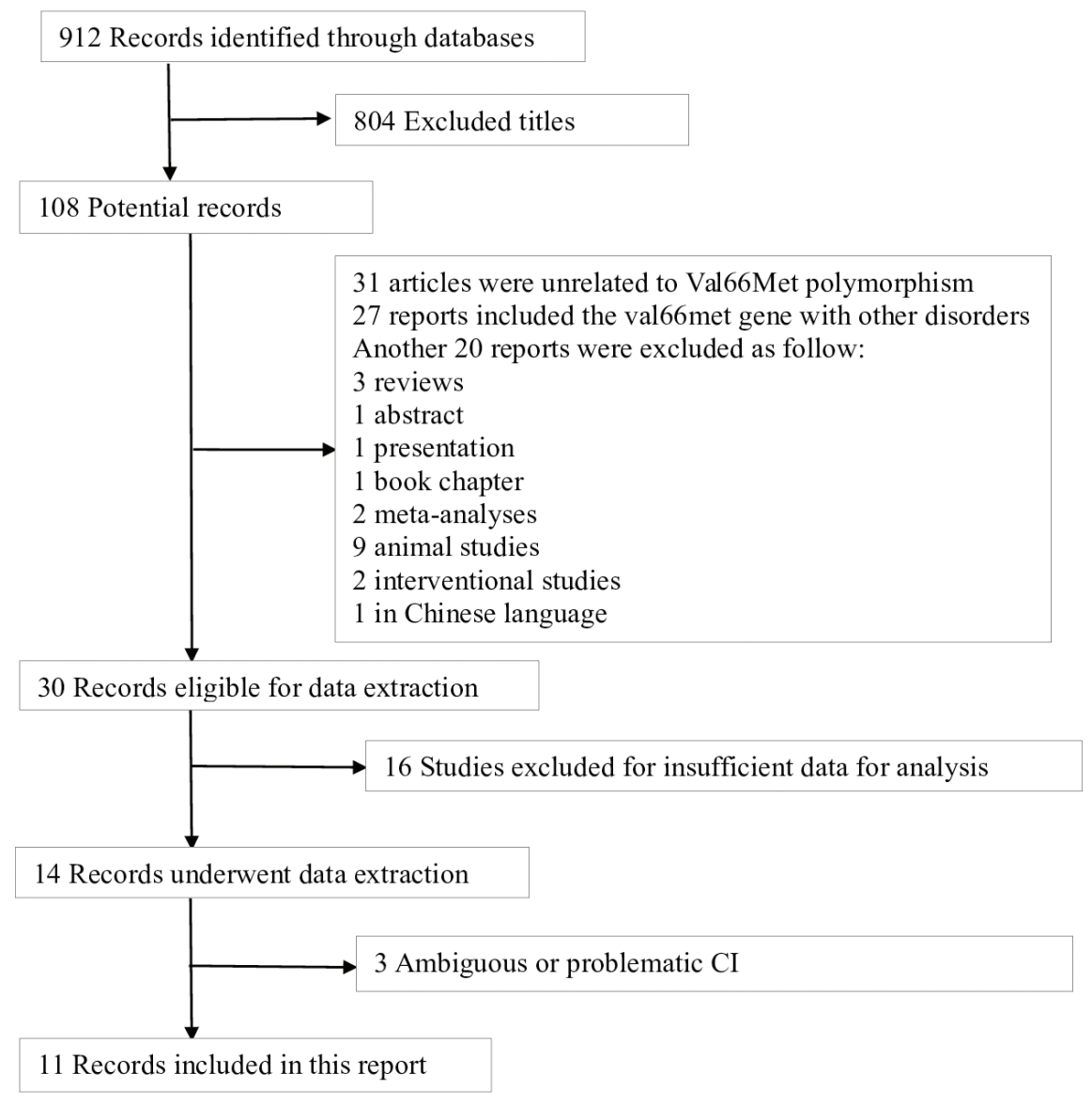

Figure 1. Flow diagram of study selection.

Table 1. Characteristics of individual studies.

\begin{tabular}{|c|c|c|c|c|c|c|c|c|c|c|c|}
\hline & \multirow[t]{2}{*}{ Study name } & \multirow[t]{2}{*}{ Year } & \multirow[t]{2}{*}{ Country } & \multirow[t]{2}{*}{ Study design } & \multicolumn{2}{|r|}{$\mathbf{n}$} & \multicolumn{2}{|c|}{ Mean age and SD } & \multirow[t]{2}{*}{$\begin{array}{l}\text { BMI cut } \\
\text { off value }\end{array}$} & \multirow[t]{2}{*}{$\begin{array}{l}\text { Hardy Weinberg } \\
\text { equation }\end{array}$} & \multirow[t]{2}{*}{ IS indexed } \\
\hline & & & & & Obese & Non-obese & Obese & Non-Obese & & & \\
\hline 1 & Ja'afaru Sani et al. & 2012 & Malaysia & Cross sectional & 132 & 432 & \multicolumn{2}{|c|}{$14.85 \pm 1.27$} & 30 & No deviation & No \\
\hline \multirow[t]{2}{*}{2} & Marti et al. & 2009 & Spain & Case control & 159 & 154 & $42.4 \pm 10.5$ & $38.6 \pm 9.0$ & 30 & No deviation & Yes \\
\hline & Nikolac et al. & 2013 & Croatia & Cohort & & & & & 30 & No deviation & Yes \\
\hline 3 & Nikolac et al. & 1972 & & & 229 & 110 & \multicolumn{2}{|c|}{$43.4 \pm 4.4$} & & & \\
\hline 4 & Nikolac et al. & 1982 & & & 275 & 64 & \multicolumn{2}{|c|}{$53.4 \pm 4.5$} & & & \\
\hline 5 & Nikolac et al. & 2006 & & & 282 & 57 & \multicolumn{2}{|c|}{$77.2 \pm 4.5$} & & & \\
\hline 6 & Sustar et al. & 2016 & Croatia & Case control & 360 & 138 & \multicolumn{2}{|c|}{ - } & 30 & No deviation & Yes \\
\hline 7 & Morales-Marin et al. & 2016 & USA & Cross sectional & 79 & 60 & \multicolumn{2}{|c|}{$36.29 \pm 14.37$} & 30 & - & Yes \\
\hline 8 & Skeledar & 2012 & Croatia & Cross sectional & 74 & 226 & \multicolumn{2}{|c|}{$10.78 \pm 4.06$} & None & No deviation & yes \\
\hline 9 & Friedel et al. & 2004 & Germany & Case control & 183 & 96 & & & $99^{\text {th }} \%$ & No deviation & yes \\
\hline 10 & Hotta et al. & 2009 & Japan & Case control & 1127 & 1733 & $49.1 \pm 13.6$ & $48.8 \pm 15.8$ & 30 & No deviation & yes \\
\hline 11 & Becker et al. & 2008 & Belgium & Case control & 532 & 197 & $37.5 \pm 0.4$ & $35.0 \pm 0.6$ & 30 & No deviation & yes \\
\hline \multirow[t]{5}{*}{12} & Thorleifsson et al. & 2009 & Iceland & Genome wide association & 5996 & 9255 & \multicolumn{2}{|c|}{$51.47(17.43)$} & 30 & No deviation & Yes \\
\hline & & & Netherlands & & 331 & 1432 & \multicolumn{2}{|c|}{$58.43(10.28)$} & & & \\
\hline & & & Denmark & & 949 & 2413 & \multicolumn{2}{|c|}{$47.17(8.73)$} & & & \\
\hline & & & European American & & 591 & 472 & \multicolumn{2}{|c|}{$47.13(12.52)$} & & & \\
\hline & & & African American & & 625 & 231 & \multicolumn{2}{|c|}{$45.28(11.75)$} & & & \\
\hline 13 & Xi et al. & 2011 & Chinese & Cross sectional & 1229 & 1619 & $11.8(2.9)$ & $12.5(3.2)$ & $95^{\text {th }} \%$ & No deviation & Yes \\
\hline
\end{tabular}




\section{Heterogeneity and sensitivity analysis}

Table 2 shows heterogeneity statistics. The variance (Tau-squared) and the proportion of variation of true effect not attributed to random error ( $I^{2}$ statistic) were higher for combined analysis. Nonetheless, the variance and $I^{2}$ were reduced after stratification and were the lowest among studies on the adults. Moreover, omission of the study by Ja'afaruSani et al. (2012) substantially reduced heterogeneity and variance among adolescent studies. With respect to sensitivity analysis, although the $95 \% \mathrm{CI}$ and $p$ value have only minimally changed with the exclusion of some studies, the magnitude of OR was not appreciably affected (Table 3).

\section{Publication bias}

Funnel plot shows some asymmetry (Figs. 5-7) indicating some degree of publication bias. However, Begg's and Egger's $p$ values were greater than 0.05 .

\section{DISCUSSION}

Successful intervention is undoubtedly based on evidence-based practice. Meta-analysis is acknowledged as being amongst the highest levels of evidence (Burns et al., 2011). It could also provide a tool for clinicians and public health specialists to design proper interventions that could help curb the escalating incidence of obesity.

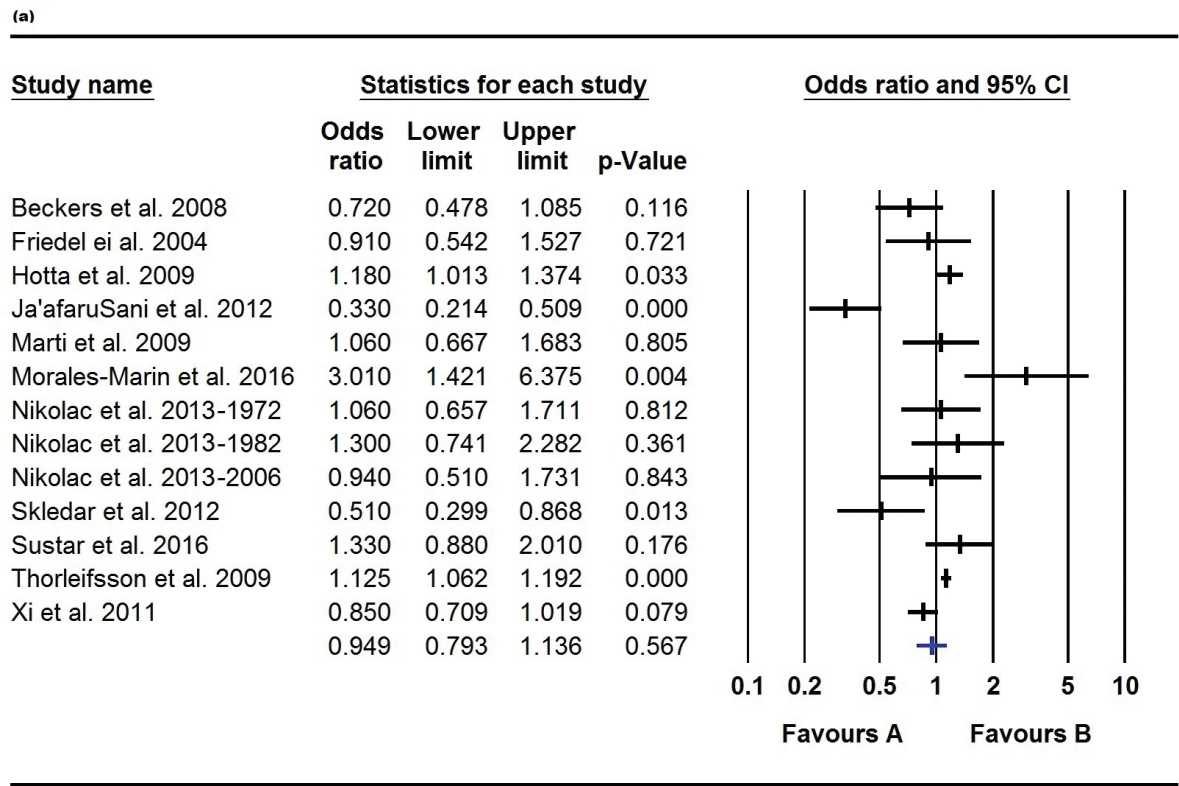

Meta Analysis

Figure 2. Forest plot-all studies.

(b)

Study name

Beckers et al. 2008

Hotta et al. 2009

Marti et al. 2009

Morales-Marin et al. 2016

Nikolac et al. 2013-1972

Nikolac et al. 2013-1982

Nikolac et al. 2013 -2006

Sustar et al. 2016

Thorleifsson et al. 2009
Statistics for each study

Odds Lower Upper

ratio limit limit $p$-Value

$\begin{array}{llll}0.720 & 0.478 & 1.085 & 0.116\end{array}$

$\begin{array}{llll}1.180 & 1.013 & 1.374 & 0.033\end{array}$

$\begin{array}{llll}1.060 & 0.667 & 1.683 & 0.805\end{array}$

$\begin{array}{llll}3.010 & 1.421 & 6.375 & 0.004\end{array}$

$\begin{array}{llll}1.060 & 0.657 & 1.711 & 0.812\end{array}$

$\begin{array}{llll}1.300 & 0.741 & 2.282 & 0.361\end{array}$

$\begin{array}{llll}0.940 & 0.510 & 1.731 & 0.843\end{array}$

$\begin{array}{llll}1.330 & 0.880 & 2.010 & 0.176\end{array}$

$\begin{array}{llll}1.125 & 1.062 & 1.192 & 0.000\end{array}$

$\begin{array}{llll}1.135 & 1.001 & 1.286 & 0.048\end{array}$
Odds ratio and $95 \% \mathrm{Cl}$

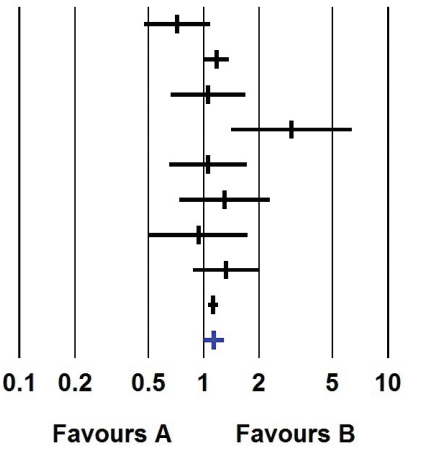

Meta Analysis

Figure 3. Forest plot-adults. 
(c)

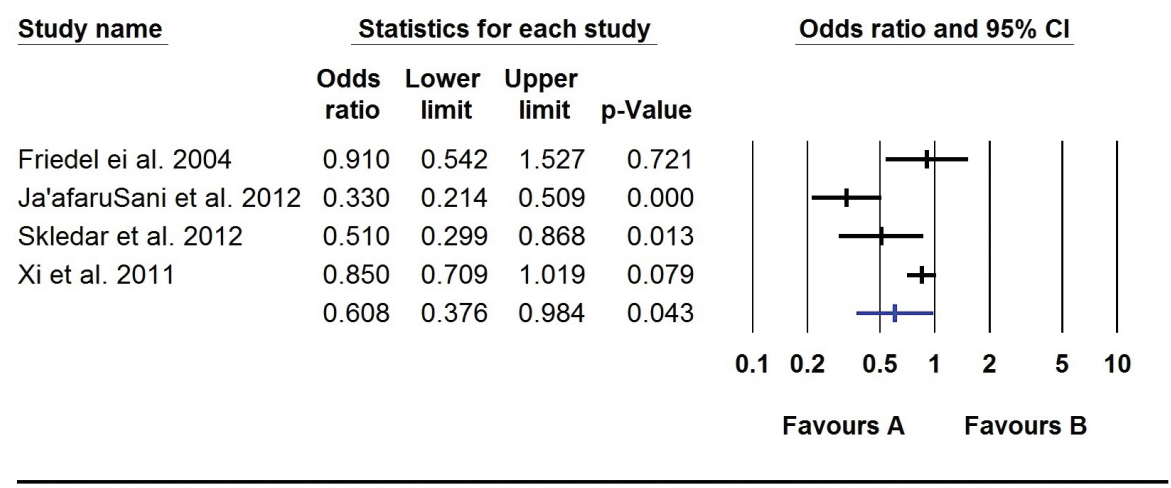

Meta Analysis

Figure 4. Forest plot- adolescents.

Table 2. Heterogeneity indices.

\begin{tabular}{lccc}
\hline Population & Pooled OR 95\% CI & Tau-squared & $\boldsymbol{I}^{\mathbf{2}}$ \\
\hline All & $0.949(0.79,1.14)$ & 0.065 & 79.73 \\
Adult & $1.14(1.01,1.29)$ & 0.010 & 37.73 \\
Children & $0.61(0.38,0.98)$ & 0.193 & 83.85 \\
Children* & $0.776(0.583,1.032)$ & 0.028 & 40.47 \\
\hline
\end{tabular}

*Ja' afaru Sani et al. removed.

Table 3. Sensitivity analysis.

\begin{tabular}{|c|c|c|c|c|c|c|}
\hline & \multicolumn{2}{|l|}{ All } & \multicolumn{2}{|c|}{ Adults } & \multicolumn{2}{|c|}{ Adolescents } \\
\hline & OR $(95 \% \mathrm{CI})$ & $p$ & OR $(95 \% \mathrm{CI})$ & $p$ & OR $(95 \% \mathrm{CI})$ & $p$ \\
\hline Beckers et al., 2008 & $0.97(0.81,1.17)$ & 0.758 & $1.16(1.06,1.26)$ & 0.001 & & \\
\hline Hotta et al., 2009 & $0.92(0.74,1.15)$ & 0.478 & $1.13(0.94,1.36)$ & 0.208 & & \\
\hline Marti et al., 2009 & $0.94(0.78,1.14)$ & 0.529 & $1.14(0.99,1.31)$ & 0.063 & & \\
\hline Morales-Marin et al., 2016 & $0.91(0.76,1.08)$ & 0.277 & $1.12(1.07,1.18)$ & 0.000 & & \\
\hline Nikolac et al., 2013-1972 & $0.94(0.78,1.14)$ & 0.530 & $1.14(0.99,1.31)$ & 0.062 & & \\
\hline Nikolac et al., 2013-1982 & $0.93(0.77,1.12)$ & 0.452 & $1.13(0.98,1.29)$ & 0.082 & & \\
\hline Nikolac et al., 2013-2006 & $0.95(0.79,1.14)$ & 0.585 & $1.14(1.01,1.31)$ & 0.048 & & \\
\hline Sustar et al., 2016 & $0.92(0.76,1.12)$ & 0.404 & $1.12(0.98,1.28)$ & 0.104 & & \\
\hline Thorleifsson et al., 2009 & $0.93(0.73,1.18)$ & 0.552 & $1.14(0.93,1.4)$ & 0.191 & & \\
\hline Friedel et al., 2004 & $0.95(0.79,1.15)$ & 0.604 & & & $0.54(0.28,1.01)$ & 0.053 \\
\hline Ja'afaruSani et al., 2012 & $1.03(0.89,1.19)$ & 0.666 & & & $0.78(0.58,1.03)$ & 0.082 \\
\hline Skledar et al., 2012 & $0.99(0.83,1.18)$ & 0.887 & & & $0.64(0.35,1.17)$ & 0.147 \\
\hline Xi et al. 2011 & $0.96(0.79,1.17)$ & 0.701 & & & $0.53(0.29,0.96)$ & 0.035 \\
\hline Overall & $0.95(0.79,1.14)$ & 0.567 & $1.13(1.001,1.29)$ & 0.048 & $0.61(0.38,0.98)$ & 0.043 \\
\hline
\end{tabular}

In this study, the results of meta-analysis support the association of obesity with Val66Met polymorphism that is confounded by age.

The random effects model was used to calculate the pooled estimate on assumption of variation among the studies included in this review (Borenstein et al., 2007). The analysis included different study designs and on mixed populations. Thus, $I^{2}$ statistic showed that there was a considerable amount of variation among studies that is not attributed to random error. Heterogeneity is inevitable in meta-analysis (Huedo-Medina et al., 2006) and it might indicate the presence of a factor with differential impact, as was the case in this study. Stratified analysis by age group reduced the true variance (tua-squared) and also reduced the $I^{2}$ whereby apparently identifying a source of heterogeneity. It identified age as an important factor to be considered when making an inference. In addition, it also showed that omission of the study performed by Ja'afaruSani et al. (2012) did not significantly influence the pooled estimate, but affected the measure of heterogeneity. The claim that a significant association of Met allele and obesity is only applicable to female gender was not evident in Ja'afaruSani et al's study. This might question the validity of such results. In general, with 


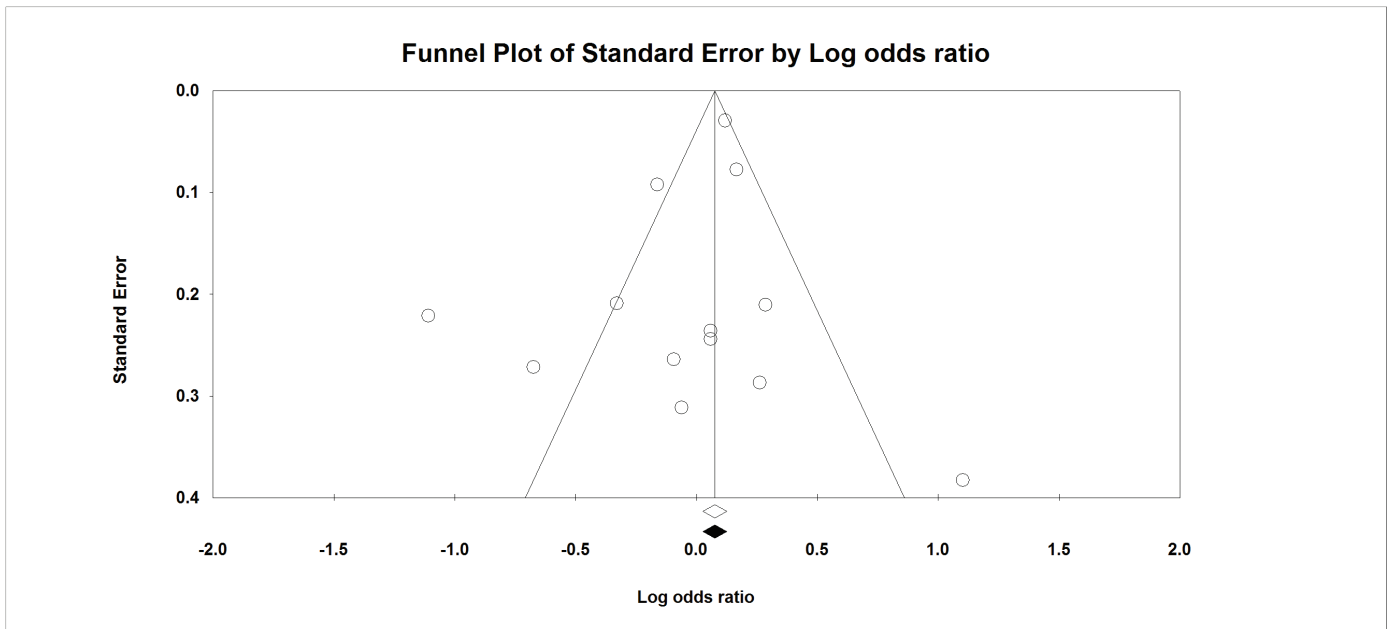

Figure 5. Funnel plot-all.

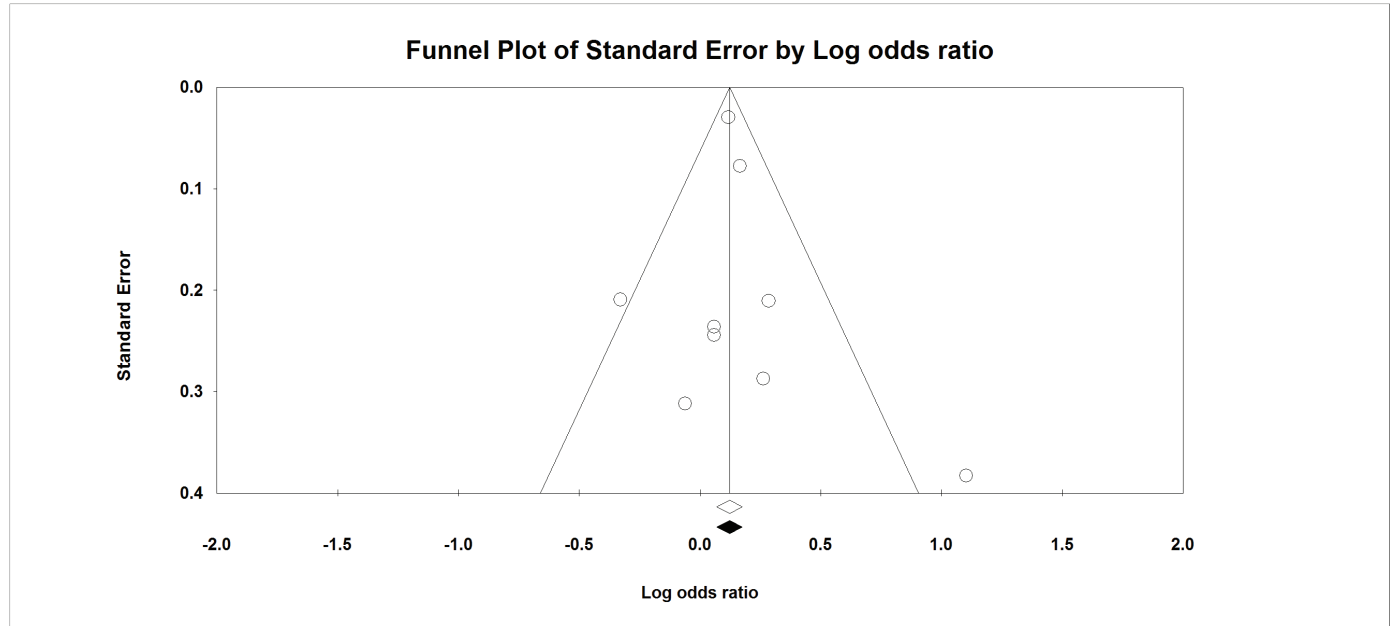

Figure 6. Funnel plot-adults.

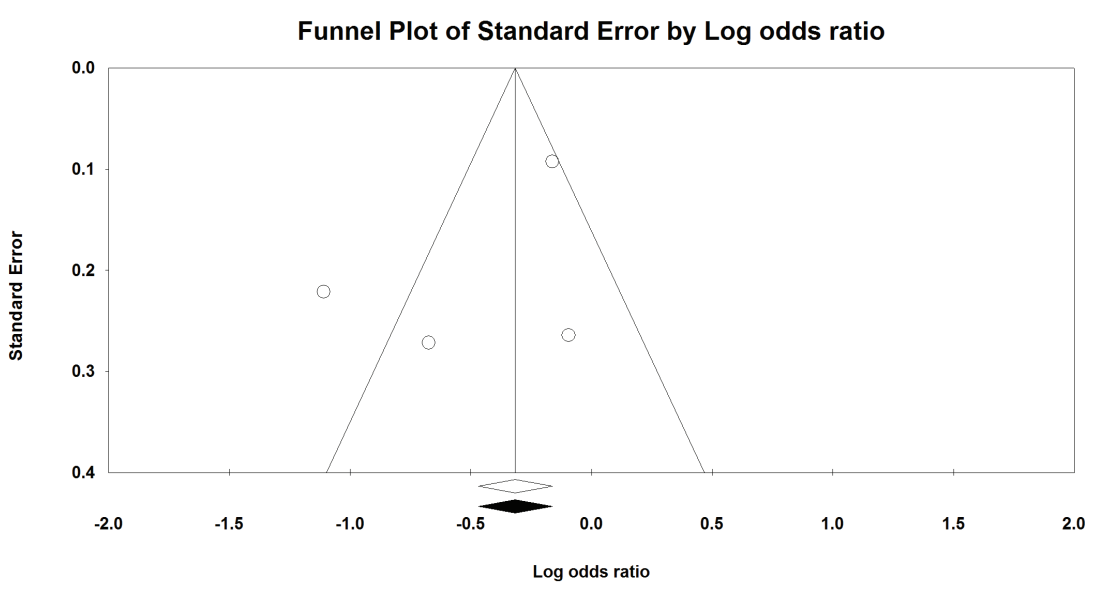

Figure 7. Funnel plot-adolescents. 
a limited number of studies, publication bias may be anticipated (Copas and Shi, 2000). However, such bias was not evident in our study as the studies included in this analysis have shown contradicting results.

BDNF was found to regulate body weight by suppressing appetite in mice (Lapchak and Hefti, 1992; Pelleymounter et al., 1995). Studies in human and rodents have further confirmed the dominant role of BDNF and TrKB in the control of energy balance. In mice, global BDNF down regulation increased feeding and body weight (Kernie et al., 2000; Rios, 2013; Xu et al., 2003). Selective deletion of BDNF in the ventromedial and dorsomedial hypothalamus caused hyperphagia and obesity in adult mice (An et al., 2015; Kernie et al., 2000; Rios et al., 2001).

Adding to the impact of $B D N F$ gene mutation on body weight, the polygenic nature of obesity itself makes it difficult to identify a single most influential gene. Nonetheless, the genetic differences of obesity have been replicated from different world populations (Lyon and Hirschhorn, 2005). This signifies the complex interaction of several factors in the causation of obesity including an individual's phenotype and disease risk factors other than BDNF.

It is relevant to acknowledge that the magnitude of effect size plays an important role in deciding whether the result is applicable for prognostic or diagnostic purposes (Chen et al., 2010). Jakobsdottir et al's (2009) logical illustration pointed out that a good genetic marker should be a good classifier (large enough) to discriminate between cases and control, which means high specificity of the applied markers. Nonetheless, the estimated OR in this study was not sizable and it is in tandem with most genetic studies.

Although we had taken all necessary precautions to ensure reliability of the results, few limitations were inevitable. First, we could not perform gender specific or age specific analysis due to lack of such information from participating studies. Several studies have reported sexual dysmorphism with particular reference to several factors implicated in obesity. Thus, there is a need to look into this aspect. Second, we only were able to perform analysis with recessive model due to the nature of extracted data. Last, most of the data emerged from Caucasian populations. This might be attributed to a high frequency of gene mutation in the Caucasians compared to the Asians. In conclusion, our findings add to evidence of genetic contribution to obesity and highlight the impact of age as a factor that might influence the interpretation.

\section{ACKNOWLEDGMENT}

The authors wish to extend their thanks to the librarians at National Defence University of Malaysia for their valuable assistance with the databases search.

\section{FINANCIAL SUPPORT}

None.

\section{CONFLICT OF INTEREST}

Authors declare that they have no conflicts of interest.

\section{REFERENCES}

An JJ, Liao G-Y, Kinney CE, Sahibzada N, Xu B. Discrete BDNF neurons in the paraventricular hypothalamus control feeding and energy expenditure. Cell Metab, 2015; 22(1):175-88.
Bachmann V, Klein C, Bodenmann S, Schäfer N, Berger W, Brugger P, Landolt HP. The BDNF Val66Met polymorphism modulates sleep intensity: EEG frequency-and state-specificity. Sleep, 2012; 35(3):335-44.

Beckers S, Peeters A, Zegers D, Mertens I, Van Gaal L, Van Hul W. Association of the BDNF Val66Met variation with obesity in women. Mol Genet Metab, 2008; 95(1-2):110-2.

Borenstein M, Hedges L, Rothstein H. Meta-analysis: Fixed effect vs. random effects, 2007. Available via Meta-analysis. com

Burns PB, Rohrich RJ, Chung KC. The levels of evidence and their role in evidence-based medicine. Plast Reconstr Surg, 2011; 128(1):305.

Chen $\mathrm{H}$, Cohen $\mathrm{P}$, Chen $\mathrm{S}$. How big is a big odds ratio? Interpreting the magnitudes of odds ratios in epidemiological studies. Commun Stat Simul Comput, 2010; 39(4):860-4.

Chen Z, Jing D, Bath K G, Ieraci A, Khan T, Siao C-J, Herrera DG, Toth M, Yang C, McEwen BS, Hempstead BL, Lee FS. Genetic variant BDNF (Val66Met) polymorphism alters anxiety-related behavior. Science, 2006; 314(5796): 140-3.

Copas J, Shi J Q. Meta-analysis, funnel plots and sensitivity analysis. Biostatistics, 2000; 1(3):247-62.

Eisenberg DP, Ianni AM, Wei S-M, Kohn PD, Kolachana B, Apud J, Weinberger DR, Berman KF. Brain-derived neurotrophic factor (BDNF) Val 66 Met polymorphism differentially predicts hippocampal function in medication-free patients with schizophrenia. Mol Psychiatry, $2013 ; 18(6): 713$

El-Gharbawy AH, Adler-Wailes DC, Mirch MC, Theim KR, Ranzenhofer L, Tanofsky-Kraff M, Yanovski JA. Serum brain-derived neurotrophic factor concentrations in lean and overweight children and adolescents. J Clin Endocrinol Metab, 2006; 91(9):3548-52.

Friedel S, Fontenla Horro F, Wermter A, Geller F, Dempfle A, Reichwald K, Smidt J, Brönner G, Konrad K, Herpertz-Dahlmann B, Warnke A, Hemminger U, Linder M, Kiefl H, Goldschmidt HP, Siegfried W, Remschmidt H, Hinney A, Hebebrand J. Mutation screen of the brain derived neurotrophic factor gene (BDNF): identification of several genetic variants and association studies in patients with obesity, eating disorders, and attention-deficit/hyperactivity disorder. Am J Med Genet B Neuropsychiatr Genet, 2005; 132(1):96-9.

Gratacòs M, González JR, Mercader JM, de Cid R, Urretavizcaya M, Estivill X. Brain-derived neurotrophic factor Val66Met and psychiatric disorders: meta-analysis of case-control studies confirm association to substance-related disorders, eating disorders, and schizophrenia. Biol Psychiatry, 2007; 61(7):911-22.

Higgins J, Thompson S. Quantifying heterogeneity in a metaanalysis. Stat Med, 2002; 21(11):1539-58.

Hosang GM, Shiles C, Tansey KE, McGuffin P, Uher R. Interaction between stress and the BDNF Val66Met polymorphism in depression: a systematic review and meta-analysis. BMC Med, 2014; 12(1):7.

Hotta K, Nakamura M, Nakamura T, Matsuo T, Nakata Y, Kamohara S, Miyatake N, Kotani K, Komatsu R, Itoh N, Mineo I, Wada J, Masuzaki H, Yoneda M, Nakajima A, Funahashi T, Miyazaki S, Tokunaga K, Kawamoto M, Ueno T, Hamaguchi K, Tanaka K, Yamada K, Hanafusa T, Oikawa S, Yoshimatsu H, Nakao K, Sakata T, Matsuzawa Y, Kamatani N, Nakamura Y. Association between obesity and polymorphisms in SEC16B, TMEM18, GNPDA2, BDNF, FAIM2 and MC4R in a Japanese population. J Hum Genet, 2009; 54(12):727.

Huedo-Medina TB, Sánchez-Meca J, Marín-Martínez F, Botella J. Assessing heterogeneity in meta-analysis: Q statistic or $\mathrm{I}^{2}$ index? Psychol Methods, 2006; 11(2):193.

Ja'afaruSani M, Hauwa'u YB, Maimuna Z, Renee LLH. Association of Brain-Derived Neurotrophic Factor (BDNF) Variant (rs6265) with Overweight/Obesity or Overfatness, and Effect of Physical Activity Levels in Adolescents Population International Journal of Science and Research. 2012;3 (10):508-14.

Jakobsdottir J, Gorin MB, Conley YP, Ferrell RE, Weeks DE. Interpretation of genetic association studies: markers with replicated 
highly significant odds ratios may be poor classifiers. PLoS Genet, 2009; 5(2): 1000337

Kernie SG, Liebl DJ, Parada LF. BDNF regulates eating behavior and locomotor activity in mice. EMBO J, 2000; 19(6):1290-300.

Khalin I, Alyautdin R, Kocherga G, Bakar MA. Targeted delivery of brain-derived neurotrophic factor for the treatment of blindness and deafness. Int J Nanomed, 2015; 10:3245.

Lapchak PA, Hefti F. BDNF and NGF treatment in lesioned rats: effects on cholinergic function and weight gain. Neuroreport, 1992; 3(5):405-8.

León-Mimila P, Villamil-Ramírez H, Villalobos-Comparán M, Villarreal-Molina T, Romero-Hidalgo S, López-Contreras B, GutiérrezVidal R, Vega-Badillo J, Jacobo-Albavera L, Posadas-Romeros C, Canizalez-Román A, Río-Navarro BD, Campos-Pérez F, Acuña-Alonzo V, Aguilar-Salinas C, Canizales-Quinteros S. Contribution of common genetic variants to obesity and obesity-related traits in mexican children and adults. PLoS One, 2013; 8(8):e70640.

Lyon HN, Hirschhorn JN. Genetics of common forms of obesity: a brief overview.Am J Clin Nutr, 2005; 82(1):215S-7S.

Marti A, Santos J, Gratacos M, Moreno-Aliaga M, Maiz A, Martinez J, Estivill X. Association between leptin receptor (LEPR) and brain-derived neurotrophic factor (BDNF) gene variants and obesity: a case-control study. Nutr Neurosci, 2009; 12(4):183-8.

Meyre D, Proulx K, Kawagoe-Takaki H, Vatin V, GutiérrezAguilar R, Lyon D, Ma M, Choquet H, Horber F, Van Hul W, Van Gaal L, Balkau B, Visvikis-Siest S, Pattou F, Farooqi IS, Saudek V, O'Rahilly S, Froguel P, Sedgwick B, Yeo GS. Prevalence of loss-of-function FTO mutations in lean and obese individuals. Diabetes, 2010; 59(1):311-8.

Miura I, Zhang J-P, Nitta M, Lencz T, Kane JM, Malhotra AK, Yabe H, Correll CU. BDNF Val66Met polymorphism and antipsychoticinduced tardive dyskinesia occurrence and severity: a meta-analysis. Schizophr Res, 2014; 152(2-3):365-72.

Monteleone P, Tortorella A, Martiadis V, Serritella C, Fuschino A, Maj M. Opposite changes in the serum brain-derived neurotrophic factor in anorexia nervosa and obesity. Psychosomatic Med, 2004; 66(5): 744-8.

Morales-Marín ME, Genis-Mendoza AD, Tovilla-Zarate CA, Lanzagorta N, Escamilla M, Nicolini H. Association between obesity and the brain-derived neurotrophic factor gene polymorphism Val66Met in individuals with bipolar disorder in Mexican population. Neuropsychiatr Dis Treat, 2016; 12:1843.

Pelleymounter MA, Cullen MJ, Wellman CL. Characteristics of BDNF-induced weight loss. Exp Neurol, 1995; 131(2):229-38.

Perkovic MN, Mustapic M, Pavlovic M, Uzun S, Kozumplik O, Barisic I, Muck-Seler D, Pivac N. Lack of association between brainderived neurotrophic factor Val66Met polymorphism and body mass index change over time in healthy adults. Neurosci Lett, 2013; 545:127-31.

Rios M. BDNF and the central control of feeding: accidental bystander or essential player? Trends Neurosci, 2013; 36(2):83-90.

Rios M, Fan G, Fekete C, Kelly J, Bates B, Kuehn R, Lechan RM, Jaenisch R. Conditional deletion of brain-derived neurotrophic factor in the postnatal brain leads to obesity and hyperactivity. Mol Endocrinol, $2001 ; 15(10): 1748-57$

Skledar M, Nikolac M, Dodig-Curkovic K, Curkovic M, Borovecki F, Pivac N. Association between brain-derived neurotrophic factor Val66Met and obesity in children and adolescents. Prog NeuroPsychopharmacol Biol Psychiatry, 2012; 36(1):136-40.
Suchanek R, Owczarek A, Paul-Samojedny M, Kowalczyk M, Kucia K, Kowalski J. BDNF val66met polymorphism is associated with age at onset and intensity of symptoms of paranoid schizophrenia in a Polish population. J Neuropsychiatry Clin Neurosci, 2013; 25(1):88-94.

Sustar A, Nikolac Perkovic M, Nedic Erjavec G, Svob Strac D, Pivac N. A protective effect of the BDNF Met/Met genotype in obesity in healthy Caucasian subjects but not in patients with coronary heart disease. Eur Rev Med Pharmacol Sci, 2016; 20(16):3417-26.

Thorleifsson G, Walters GB, Gudbjartsson DF, Steinthorsdottir V, Sulem P, Helgadottir A, Styrkarsdottir U, Gretarsdottir S, Thorlacius S, Jonsdottir I, Jonsdottir T, Olafsdottir EJ, Olafsdottir GH, Jonsson T, Jonsson F, Borch-Johnsen K, Hansen T, Andersen G, Jorgensen T, Lauritzen T, Aben KK, Verbeek AL, Roeleveld N, Kampman E, Yanek LR, Becker LC, Tryggvadottir L, Rafnar T, Becker DM, Gulcher J, Kiemeney LA, Pedersen O, Kong A, Thorsteinsdottir U, Stefansson K. Genome-wide association yields new sequence variants at seven loci that associate with measures of obesity. Nat Genet, 2009; 41(1):18.

Timpano KR, Schmidt NB, Wheaton MG, Wendland JR, Murphy DL. Consideration of the BDNF gene in relation to two phenotypes: hoarding and obesity. J Abnormal Psychol, 2011; 120(3):700.

Wang YC, McPherson K, Marsh T, Gortmaker SL, Brown M. Health and economic burden of the projected obesity trends in the USA and the UK. Lancet, 2011; 378(9793):815-25.

WHO. (2014a). Global health observatory. Available via http:// www.who.int/gho/ncd/risk_factors/obesity_text/en/ (Accessed 20 February 2018).

WHO. (2014b). Global strategy on diet, physical activity and health. Available via http://www.who.int/dietphysicalactivity/childhood/en/ (Accessed 20 February 2018).

Wu L, Xi B, Zhang M, Shen Y, Zhao X, Cheng H, Hou D, Sun D, Ott J, Wang X, Mi J. Associations of six single nucleotide polymorphisms in obesity-related genes with BMI and risk of obesity in Chinese children. Diabetes, 2010; 59(12):3085-9.

Xi B, Wang C, Wu L, Zhang M, Shen Y, Zhao X, Wang X, Mi J. Influence of physical inactivity on associations between single nucleotide polymorphisms and genetic predisposition to childhood obesity. Am J Epidemiol, 2011; 173(11):1256-62.

Xu B, Goulding EH, Zang K, Cepoi D, Cone RD, Jones KR, Tecott LH, Reichardt LF. Brain-derived neurotrophic factor regulates energy balance downstream of melanocortin-4 receptor. Nat Neurosci, 2003; 6(7):736

How to cite this article:

Daher AM, Lugova H, Kutty MK, Khalin I. Association of the Val66met polymorphism and risk of obesity, systematic review and meta-analysis. J Appl Pharm Sci, 2020; 10(1): 108-115. 